\title{
JAN PAWEŁ II I ARCHEOLOGIA CHRZEŚCIJAŃSKA
}

Niemal natychmiast po otrzymaniu święceń kapłańskich ksiądz Karol Wojtyła wyjechał na studia do Rzymu ${ }^{1}$. Wspominając tamte czasy pisał: „Przyjechałem do Rzymu niosąc w sobie wielkie pragnienie, aby zwiedzanie Wiecznego Miasta rozpocząć od katakumb"2, a w rozmowie z młodzieżą w marcu 1984 roku mówił: „Przez długie lata nosiłem w sercu obraz Rzymu pierwszych chrześcijan, katakumb, i w pierwszych dniach mojego pobytu w Rzymie, w listopadzie 1946 roku, krążyłem po ulicach, wstępowałem do kościołów, ale nie mogłem odnaleźć owego obrazu wyrytego w moim sercu. W końcu dotarłem do katakumb, zwiedziłem pierwsze bazyliki chrześcijańskie, gdzie wyczuwało się nieomal obecność pierwszych chrześcijan, pierwszych chrześcijańskich pokoleń. Dopiero wtedy rozpoznałem Rzym, który żył w moim sercu [...]"3.

Już jako papież, Jan Paweł II wspierał prace papieskich instytucji - Pontificia Commissione di Archeologia Sacra (PCAS) i Pontificio Istituto di Archeologia Cristiana (PIAC), powołanych do „badania i upowszechniania tego cennego dziedzictwa zabytków Kościoła, a zwłaszcza katakumb w Rzymie i we Włoszech"4. Kontynuował tym samym, z pełną świadomością jego znaczenia, dzieło swoich poprzedników na tronie Piotrowym ${ }^{5}$.

Dnia 11 grudnia 1984 r. Jan Paweł II spotkał się z pracownikami i studentami założonego przez Piusa XI Papieskiego Instytutu Archeologii Chrześcijańskiej (PIAC). Okazji dostarczyło sympozjum zorganizowane dla uczczenia

${ }^{1}$ Por. Życiorys Karola Wojtyty (autograf, 8 kwietnia 1948 r.; sygn. AUJ, S III 246).

2 Jan Paweł II, Dar i tajemnica. W pięćdziesiąta rocznicę święceń kapłańskich, Kraków 2005, 51.

3 Jan Paweł II. Autobiografia, wybrała i ułożyła J. Kiliańczyk-Zięba, Warszawa 2003, 60; Jan Pawet II odpowiada na pytania mtodzieży, OsRomPol 5 (1984) nr 3, s. 9.

${ }^{4}$ Starożytne zabytki Kościoła mówiq̨ o wierze pierwszych chrześcijan. Przesłanie Jana Pawła II z okazji 150. rocznicy powstania Papieskiej Komisji Archeologii Sakralnej, OsRomPol 23 (2003) nr 5, s. 11, lub VoxP 22 (2002) t. 42-43, 12.

${ }_{5}$ Por. Le catacombe, luogo privilegiato di preghiera e di pellegrinaggio. In occasione dello storico appuntamento del Grande Giubileo (1996), w: Insegnamenti di Giovanni Paolo II, 1996 (gennaio - giugno), XIX/1, Città del Vaticano 1998, 1466-1469. 
60-lecia Instytutu i 1600. rocznicy śmierci papieża Damazego (368 - 384), nazywanego patronem archeologii chrześcijańskiej, ponieważ jego niezaprzeczalną zasługą było odnajdywanie, konserwacja i restaurowanie grobów męczenników, które do dziś stanowią dla badaczy ważny punkt odniesienia, m.in. w ustalaniu chronologii wczesnochrześcijańskich cmentarzy ${ }^{6}$. Zwracając się do uczestników sympozjum, Papież podkreślał rolę Damazego w dziele ocalenia heroicznych postaci i ich czynów przed zapomnieniem, ale uwydatniał także znaczenie działalności archeologów, których badania nie tylko wzbogacają naukę, lecz także dostarczają chrześcijanom naszej epoki źródeł wiedzy o narodzinach chrześcijaństwa. Wydarzenia, których rocznice wówczas świętowano, Papież określił jako „due avvenimenti, che si collegano insieme, un po' come la sorgente con il corso del fiume",

Okazją do spotkania z przedstawicielami archeologii chrześcijańskiej było również 150-lecie powstania, założonej przez Piusa IX, Papieskiej Komisji Archeologii Sakralnej (PCAS), pod której pieczą pozostają wczesnochrześcijańskie zabytki Rzymu i Italiii ${ }^{8}$, Zwracając się, do Przewodniczącego Komisji Arcybiskupa Francesco Marchisano, Jan Paweł II nawiązał do motu proprio Piusa XI, który dbał o to, ,,aby starożytne zabytki Kościoła były zabezpieczone w jak najlepszy sposób, udostępniane badaczom oraz otaczane kultem przez wiernych ze wszystkich krajów"9 Ze swej strony Papież zapewnił współpracowników Komisji o szczerej życzliwości, dodając, że „dzięki ich pracy Kościół może coraz lepiej poznawać spuściznę pozostawioną przez pierwsze pokolenia chrześcijan" ${ }^{10}$, a ,dziedzictwo to, wraz ze swym milczącym i niezmiennym przesłaniem, pomaga Ludowi Bożemu dochować wierności depositum fidei, które otrzymał jako cenny skarb i którego musi starannie strzec"11.

Mówiąc o „,szczególnej trosce, jaką od najdawniejszych czasów papieże rzymscy otaczali zabytki chrześcijaństwa” ${ }^{12}$, podkreślał, że „,kierowali się jak zawsze - względami duchowymi i duszpasterskimi”"13. Większość wypowiedzi Jana Pawła II dowodzi, że również On oczekiwał od archeologów nie tylko odnajdywania i „odpowiedniej konserwacji 'pamiątek ludu Bożego', ale też

${ }^{6}$ Por. Saecularia Damasiana. Atti del Convegno Internazionale per il XVI centenario della morte di papa Damaso I (11 XII 384 - 10/12 XII 1984), Città del Vaticano 1986.

7 Il Papa al Convegno su S. Damaso. Il ruolo dell'archeologia nella cultura cristiana, OsRom 124 (1984) nr 285, s. 5.

${ }^{8}$ Por. B. Iwaszkiewicz-Wronikowska, Papieska Komisja Archeologii Chrześcijańskiej. Sto pięćdziesiąt lat działalności (1852-2002), VoxP 22 (2002) t. 42-43, 515-523; zob. też Regulamin Papieskiej Komisji Archeologii Sakralnej, tłum. D. Wronikowska, przekład przejrzał S. Longosz, tamże, s. 25-29.

${ }^{9}$ Por. Starożytne zabytki Kościoła, art. cyt., s. 11-12 lub VoxP t. 42-43, s. 12.

${ }^{10}$ Tamże, s. 12 lub VoxP t. 42-43, s. 13.

11 Tamże.

12 Tamże, s. 11 lub VoxP t. 42-43, s. 12.

13 Tamże, s. 12 lub VoxP t. 42-43, s. 12. 
badania i rozpowszechniania zawartego w nich religijnego i kulturalnego przesłania" ${ }^{14}$, które uważał za wciąż aktualne. Chciał, żeby dla współczesnych chrześcijan inspiracją były prostota, skromność i egalitaryzm katakumbowych pochówków. Widział w nich bowiem przejawy panujących w starożytnym Kościele „takich wartości, jak solidarność i, jeszcze ważniejsze, miłosierdzie”15 i wyrażał nadzieję, że „odkrywając za pośrednictwem zabytków i pamiątek stałość wiary pierwszych chrześcijan, nowe pokolenia będą mogły z większą odwagą żyć zgodnie z Ewangelią, również za cenę osobistych wyrzeczeń" 16 .

Dobrą okazją dla propagowania, na masową wręcz skalę, ,,bogatego dziedzictwa wiary, sztuki i kultury" ${ }^{17}$ pierwszych wieków chrześcijaństwa był jubileusz roku 2000. Pracownicy PCAS włożyli wiele wysiłku w odrestaurowanie katakumb i odnowienie zbiorów muzealnych, a także w przeprowadzenie prac konserwatorskich i remontowych umożliwiających bezpiecznie udostępnienie zabytków pielgrzymom. Na spotkaniu w Sali Konsystorza, które odbyło się w dniu 7 czerwca 1996 roku, papież przyjął członków i współpracowników Komisji oraz dyrektorów pięciu rzymskich katakumb otwartych dla zwiedzających (San Callisto, San Sebastiano, Santa Domitilla, Santa Priscilla, Sant'Agnese). Przypominając działania swoich poprzedników na rzecz odkrywania i restaurowania katakumb, jeszcze raz podkreślał znaczenie, jakie te świadectwa wczesnochrześcijańskiej żarliwości wciąż mają dla pielgrzymów przybywających do Wiecznego Miasta ${ }^{18}$.

Już po podsumowaniu rezultatów działalności Komisji podczas Wielkiego Jubileuszu, Jan Paweł II dziękował „za pomoc w głoszeniu Chrystusowej nowiny w dzisiejszym świecie”19. I dodawał: „Współczesny pielgrzym, często zdezorientowany i wątpiący, przebywając szlaki wędrówki pierwszych chrześcijan i uznając za swoje ich sposoby wyrażania pobożności, może łatwiej odnaleźć drogę prowadzącą do odkrycia własnej tożsamości religijnej"20.

Jan Paweł II wyznaczał zatem archeologii chrześcijańskiej dwa cele: badanie śladów chrześcijan z pierwszych wieków, ale także odnajdywanie w nich inspiracji do ,nowej ewangelizacji, modlitwy i przeżycia kulturalnego dla pielgrzymów z całego świata"21.

14 Tamże, s.12 lub VoxP t. 42-43, s. 13.

15 Przemówienie Jana Pawła II do uczestników zebrania ogólnego Papieskiej Komisji Archeologii Sakralnej, tłum. D. Wronikowska, VoxP 22 (2002) t. 42-43, 16.

${ }^{16}$ Starożytne zabytki Kościoła 4, s. 12 lub VoxP t. 42-43, s. 14.

17 Jw. lub VoxP t. 42-43, s. 14.

18 Por. Le catacombe, art. cyt., passim.

19 Przemówienie Jana Pawła II do uczestników zebrania ogólnego, VoxP t. 42-43, s. 17.

20 Tamże.

21 Tamże, s. 15. 


\section{GIOVANNI PAOLO II E ARCHEOLOGIA CRISTIANA}

\section{(Riassunto)}

Dai discorsi di Giovanni Paolo II si evince che, come il compito principale dell'archeologia cristiana, egli vedeva la riscoperta delle testimonianze di vita dei primi cristiani, le quali dovevano poi essere usate come esempi validi per i cristiani di oggi. 